\title{
Separation of Long Double-Stranded DNA by Nanoparticle-Filled Capillary Electrophoresis
}

\author{
Ming-Feng Huang, Yi-Chun Kuo, Chih-Ching Huang, and Huan-Tsung Chang* \\ Department of Chemistry, National Taiwan University, Section 4, Roosevelt Road, Taipei, Taiwan, R.O.C.
}

\begin{abstract}
We present the first example of the analysis of long double-stranded (ds) DNA molecules by nanoparticlefilled capillary electrophoresis (NFCE). To avoid aggregation of the gold nanoparticles (GNPs) and to allow strong interactions with the DNA molecules, the gold nanoparticles were modified with poly(ethylene oxide) (PEO) via noncovalent bonding to form gold nanoparticle/ polymer composites (GNPPs). The neutral GNPPs are heavy ( 2.0 $\times 10^{8} \mathrm{~g} / \mathrm{mol}$ for the $32-\mathrm{nm} \mathrm{GNP}$ ) and thus slow the DNA molecules that they encounter during the electrophoretic process. Compared to linear polymer solutions, such as hydroxyethyl cellulose and PEO, the GNPPs provide greater efficiency and require significantly shorter times to separate long dsDNA. The separation of $\lambda$-DNA $(0.12-23.1 \mathrm{kbp})$ by NFCE at $-250 \mathrm{~V} / \mathrm{cm}$ was accomplished in $3 \mathrm{~min}$. The ability to separate high molecular weight DNA markers (8.27-48.5 kbp) with plate numbers greater than $10^{6}$ suggests that this novel method may hold great promise for the analysis of longstranded DNA molecules such as chromosomes. Moreover, this method is simple and affordable when compared to those that use micro- and nanofabricated devices for separating long DNA molecules.
\end{abstract}

The efficient separation of long-stranded DNA is important in many genome projects and is conducted usually by a standard method, pulsed field gel electrophoresis, ${ }^{1}$ that is slow, with running times ranging from several hours to several days. Although capillary electrophoresis (CE) using entangled polymer solutions is fast and highly efficient for the separation of DNA molecules with different sizes or sequences, ${ }^{2-4}$ it is not suitable for high-efficiency separations of long-stranded DNA (>1000 bp) because the electrophoretic mobility becomes independent of molecular size or the DNA is trapped by the sieving matrix. ${ }^{5}$ To overcome this problem, a number of $\mathrm{CE}$-based techniques have been developed and tested with varying degrees of success, including the use of ultradilute polymer solutions ${ }^{6-8}$ and pulsed-

* To whom correspondence should be addressed. Phone: 011-886-223621963. Fax: 011-886-2-23621963. E-mail: changht@ntu.edu.tw.

(1) Cole, K. D.; Tellez, C. M. Biotechnol. Prog. 2002, 18, 82-87.

(2) Kim, Y.; Yeung, E. S. J. Chromatogr., A 1997, 781, 315-325.

(3) Han, F.; Huynh, B. H.; Ma, Y.; Lin, B. Anal. Chem. 1999, 71, 23852389.

(4) Zhou, H.; M iller, A. W.; Sosic, Z.; Buchholz, B.; Barron, A. E.; Kotler, L.; Karger, B. L. Anal. Chem. 2000, 72, 1045-1052.

(5) Mitnik, L.; Salomé, L.; Viovy, J. L.; Heller, C. J. Chromatogr., A 1995, 710, 309-321.

192 Analytical Chemistry, Vol. 76, No. 1, January 1, 2004 field CE. 9,10 Recently, many micro- and nanofabricated devices, such as microfabricated arrays of obstacles, ${ }^{11}$ entropy trap arrays, ${ }^{12,13}$ asymmetric obstacle arrays, ${ }^{14}$ and a DNA prism, ${ }^{15}$ have been developed to overcome the problem of time delays. These techniques, however, generally require sophisticated fabrication processes and complicated separation systems when compared to $\mathrm{CE}$ using ultradilute polymer solutions.

The separation of double-stranded (ds) DNAs (2-23.1 kbp) has been achieved by CE under a high field $(270 \mathrm{~V} / \mathrm{cm})$ in the presence of ultradilute hydroxyethyl cellulose (HEC; $0.002 \%$ this concentration is far below its entanglement (overlap) threshold $\left(c^{*}\right)$ of $0.40 \%$. ${ }^{16}$ It is noted that for the concentration above $c^{*}$ the interaction of the polymers begins to affect bulk solution properties such as viscosity. The separation mechanism (transient entanglement mechanism) suggested by Barron et al. and modeled by Hubert et al. ${ }^{17}$ is that the DNA molecules drag the polymer molecules along as they are encountered during migration, which has been supported by other studies showing dynamic formation and deformation of U-shape in DNA conformation. ${ }^{5,18}$ Since then, ultradilute polymer solutions have been used for separation of long DNA in a constant field. ${ }^{19-24}$

(6) Barron, A. E.; Soane, D. S.; Blanch, H. W. J. Chromatogr. 1993, 652, $3-16$.

(7) Barron, A. E.; Sunada, W. M.; Blanch, H. W. Electrophoresis 1996, 17, 744757.

(8) Braun, B.; Blanch, H. W.; Prausnitz, J. M . Electrophoresis 1997, 18, $1994-$ 1997.

(9) Kim, Y.; M orris, M. D. Anal. Chem. 1995, 67, 784-786.

(10) Oana, H.; Doi, M .; Ueda, M .; Yoshikawa, K. Electrophoresis 1997, 18, 1912 1915.

(11) Volkmuth, W. D.; Austin, R. H. Nature 1992, 358, 600-602.

(12) Han, J.; Craighead, H. G. Science 2000, 288, 1026-1029.

(13) Han, J.; Craighead, H. G. Anal. Chem. 2002, 74, 394-401.

(14) Chou, C.-F.; Bakajin, O.; Turner, S. W. P.; Duke, T. A. J.; Chan, S. S.; Cox, E. C.; Craighead, H. G.; Austin, R. H. Proc. Natl. Acad. Sci. U.S.A. 1999, 96, 13762-13765.

(15) Huang, L. R.; Tegenfeldt, J . O.; Kraeft, J. J.; Sturm, J . C.; Austin, R. H.; Cox, E. C. Nat. Biotechnol. 2002, 20, 1048-1051.

(16) Barron, A. E.; Blanch, H. W.; Soane, D. S. Electrophoresis 1994, 15, 597615.

(17) Hubert, S. J.; Slater, G. W.; Viovy, J.-L. Macromolecules 1996, 29, 10061009.

(18) Shi, X.; Hammond, R. W.; Morris, M. D. Anal. Chem. 1995, 67, 11321138.

(19) Sunada, W. M.; Blanch, H. W. Electrophoresis 1998, 19, 3128-3136.

(20) Dolnik, V.; Gurske, W. A. Electrophoresis 1999, 20, 3373-3380.

(21) Schwinefus, J. J.; Hammond, R. W.; Oana, H.; Wang, S.-C.; Carmejane, O. D.; Bonadio, J.; M orris, M. D. M acromolecules 1999, 32, 4625-4630.

(22) Raucci, G.; M aggi, C. A.; Parente, D. Anal. Chem. 2000, 72, 821-826.

(23) Desruisseaux, C.; Drouin, G.; Slater, G. W. M acromolecules 2001, 34, 52805286.

(24) Todorov, T. I.; M orris, M. D. Electrophoresis 2002, 23, 1033-1044. 
Recently we have developed two new DNA separation techniques using $C E .^{25,26}$ Using the first of these methods, we demonstrated, in the presence of electroosmotic flow (EOF), the separation of DNA ranging in size from $8 \mathrm{bp}$ to $23.1 \mathrm{kbp}$ by $\mathrm{CE}$ using $1.0 \%$ poly(ethylene oxide) (PEO) that was introduced into the capillary by EOF after sample injection via pressure means. ${ }^{25}$ Although this technique allows a rapid ( $15 \mathrm{~min}$ ) separation of DNA with such a wide size range, it does not allow an efficient separation of longer DNA. The second technique involves the separation of DNA in the presence of gold nanoparticles (GNPS) ${ }^{26}$ The separation of DNA ranging in size from 8 to 2176 bp was accomplished in 5 min using 0.2\% PEO (M W 8000 000) (c* = $0.07 \%$ radius of gyration $227 \mathrm{~nm}$ ) containing $56-\mathrm{nm} \mathrm{GN} \mathrm{Ps} .{ }^{27}$ With such a low-viscosity PEO solution ( $<15 \mathrm{CP}$ ), we have encountered no difficulty in filling the capillary.

The main goal of this study is to develop a new CE method for the rapid and highly efficient separation of long DNA. In this paper, we describe a CE technique, which we call nanoparticlefilled CE (NFCE), using polymer-modified gold nanoparticles (GNPPS). The separations of high molecular weight (HM W) DNA with sizes ranging from 8.27 to $48.5 \mathrm{kbp}$ and $\lambda$-DNA (0.12 to 23.1 $\mathrm{kbp}$ ) were accomplished within 6 and $5 \mathrm{~min}$, respectively. Based on the results presented in this study, we propose a possible separation mechanism.

\section{EXPERIMENTAL SECTION}

Chemicals. Sodium tetrachloroaurate(III) dehydrate was obtained from Sigma (St. Louis, MO). Trisodium citrate was obtained from Riedel-de Haën (Seelze, Germany). PEO (MW 8000000 ), and poly(vinylpyrrolidone) (PVP) (MW 1300000 ) were purchased from Aldrich (M ilwaukee, WI). Glycine was purchased from ICN Biomedicals Inc. (Aurora, OH). Ethidium bromide (EtBr) was obtained from Pharmacia Biotech. (Uppsala, Sweden). Please note that $E t B r$ is a highly carcinogenic compound and must be handled wearing gloves. Lambda DNA HindIII digest ( $\lambda$-DNA) was purchased from Amersham Pharmacia Biotech. Inc. (Piscataway, NJ), and the HM W DNA marker was purchased from Life Technologies (Rockville, MD). The glycine-citrate (GC) buffer consisted of glycine $\left(\mathrm{pK}_{\mathrm{a} 1}=2.35\right.$ and $\left.\mathrm{pK}_{\mathrm{a} 2}=9.778\right)$ and trisodium citrate $\left(\mathrm{pK}_{\mathrm{a} 1}=3.128, \mathrm{pK}_{\mathrm{a} 2}=4.761\right.$, and $\left.\mathrm{pK}_{\mathrm{a} 3}=6.396\right)$ used to adjust the $\mathrm{pH}$. In this paper, the molarity of the $\mathrm{GC}$ buffers refers to that of glycine.

Apparatus. A double-beam UV-visible spectrophotometer (Cintra 10e, GBC Scientific Equipment Pty Ltd., Dandenong, Victoria, Australia) was used to measure the absorbance of the GNPS and the GNPPs. A fluorometer (Aminco-Bowman Series 2, ThermoSpectronic, Pitsford, NY) was used to measure the fluorescence of EtBr in the presence of the GNPPs. An H7100 TEM (Hitachi High-Technologies Corp., Tokyo, Japan) operating at $75 \mathrm{keV}$ was used to collect TEM images of as-prepared GNPS.

We have described the basic design of the separation system previously. ${ }^{28}$ B riefly, a high-voltage (HV) power supply (Gamma High Voltage Research Inc., Ormond Beach, FL) was used to drive electrophoresis. The entire detection system was enclosed in a

(25) Chiu, T.-C.; Chang, H.-T. J. Chromatogr., A 2002, 979, 299-306.

(26) Huang, M .-F .; Huang, C.-C.; Chang, H.-T. Electrophoresis 2003, 24, 28962902.

(27) Devanand, K.; Selser, J. C. M acromolecules 1991, 24, 5943-5947.

(28) Chen, H.-S.; Chang, H.-T. Electrophoresis 1998, 19, 3149-3153. black box with an HV interlock. The high-voltage end of the separation system was housed in a plexiglass box for safety. A 4.0-mW He-Ne laser with output at $543.5 \mathrm{~nm}$ (model 1675, Uniphase, Manteca, CA) was used for excitation. The emission light was collected with a $10 \times$ objective (numeric aperture 0.25 ). One RG 610 cutoff filter (Edmund Industrial Optics, Barrington, NJ) was used to block scattered light before the emitted light reached the phototube (R928, Hamamatsu Photonics K. K., Shizuoka-Ken, Japan). The fluorescence signal was transferred directly through a $10-\mathrm{k} \Omega$ resistor to a 24-bit A/ D interface at 10 $\mathrm{Hz}$ (Borwin, J M BS Developments, Le Fontanil, France) and stored in a PC. Capillaries (Polymicro Technologies, Phoenix, AZ) with $75-\mu \mathrm{m}$ i.d. and $365-\mu \mathrm{m}$ 0.d. were dynamically coated with 5.0\%PVP overnight and then with $0.5 \% \mathrm{PEO}$ for $12 \mathrm{~h}$ prior to use in DNA separations. The two-layer dynamic coating has been found more effective to suppress EOF and minimize the interaction with DNA and proteins when compared to a one-layer coating with either PEO or PVP. 26,29

Synthesis of GNPs and GNPPs.The 32-nm GNPs were prepared according to reported methods. ${ }^{30}$ B riefly, a $0.01 \% \mathrm{AuCl}_{4}{ }^{-}$ solution $(50 \mathrm{~mL}$ ) was heated under reflux and then $1 \%$ trisodium citrate $(0.5 \mathrm{~mL})$ was added. The solution was heated under reflux for another $8 \mathrm{~min}$, during which time the solution changed color from pale-yellow to purple, indicating the formation of the 32-nm GNPs (density $19.3 \mathrm{~g} / \mathrm{cm}^{3}$ ). The solution was cooled to room temperature and its UV-visible absorption spectrum was recorded, showing that the surface plasmon resonance (SPR) band was at $528 \mathrm{~nm}$. The concentration of the original 32-nm GNPs is $\sim 0.27 \mathrm{nM}\left(1.6 \times 10^{11}\right.$ particles $\left./ \mathrm{mL}\right),{ }^{31}$ which we denote in this study as $1 \times$. The TEM images (not shown) further confirm that the size of the GNPs is $32( \pm 9 \%) n$ m. $^{30}$

A $0.5 \%$ PEO solution ( $50 \mathrm{~mL}$ ) was added to as-prepared $1 \times$ of 32-nm GNPs ( $200 \mathrm{~mL})$, and then the mixture was left for at least $1 \mathrm{~h}$ before being centrifuged at $12,000 \mathrm{rpm}$ for $10 \mathrm{~min}$ to remove the excess polymer. The pellet was washed with $10 \mathrm{mM} \mathrm{GC}$ buffer ( $\mathrm{pH}$ 7.0) and centrifuged at $12000 \mathrm{rpm}$ (relative centrifugal force $16421 \mathrm{~g}$ ) for $10 \mathrm{~min}$. After the process was repeated twice, the GNPPs were collected and then redispersed in $10 \mathrm{mM} \mathrm{GC}$ buffers ( $\mathrm{pH}$ values ranging from 7.0 to 9.0). In the presence of excess PEO, GNPs were almost not existent in the solution supported by the results from CE runs (see later). Since the molar absorptivities of the GNP and GNPP at $530 \mathrm{~nm}$ are about the same, the concentration of the GNPPS was estimated by the ratio of the absorbance at $530 \mathrm{~nm}$ of the GNPPs relative to that of the GNPs.

NFCE. B efore conducting separations, the dynamically coated capillary was flushed with deionized water to remove PEO and then filled with the GNPPs by applying a low pressure (syringe pushing). DNA samples were hydrodynamically injected at the cathode end into the coated capillary at a 20-cm height for $5 \mathrm{~s}$, and the separations were conducted at -5 or $-10 \mathrm{kV}$. After each run, the solution of GNPPs was flushed out using low pressure.

\section{RESULTS AND DISCUSSION}

Why GNPPs? Capillaries and microfabricated channels coated with GNPs have been employed to enhance the separation

(29) Wang, S.-J .; Tseng, W.-L.; Lin Y.-W.,; Chang, H.-T. J. Chromatogr., A 2002 $979,261-270$

(30) Frens, G. Nature 1973, 241, 20-22.

(31) Jana, N. R.; Gearheart, L.; M urphy, C. J. Langmuir 2001, 17, 6782-6786. 
efficiency of small isomers in CE and microchip CE. ${ }^{32-34}$ The separation of DNA (0.12-23.1 kbp) by CE using a GNP-coated capillary filled with $0.3 \times$ GNPs or $10 \mathrm{mM} \mathrm{GC}$ buffer was unsuccessful (only one broad peak detected). Based on the fact that GNPs are stable in the presence of a number of linear polymers, such as PVP, PEO, and HEC, 35 GNPPs were made and tested as agents for DNA separation. PEO molecules attach to the surfaces of the nanoparticles through their hydrophobic regions, which leaves their hydrophilic groups available to interact with the polar dispersion media. ${ }^{36,37} \mathrm{~A}$ very small electrophoretic mobility $\left(7.01 \times 10^{-5} \mathrm{~cm}^{2} \mathrm{~V}^{-1} \mathrm{~s}^{-1}\right)$ relative to that of the GNPs $\left(4.15 \times 10^{-4} \mathrm{~cm}^{2} \mathrm{~V}^{-1} \mathrm{~s}^{-1}\right)$ indicates that the negative-charge density of the GNPPs is lowered as a result of adsorption of the neutral polymer molecules on the GNPs. The adsorption of polymers also makes the GNPPs stable in the presence of $E t B r$, which is a situation supported by the fact that no aggregation occurs and there is only a slight red shift $(2 \mathrm{~nm})$ in the SPR band mainly due to the change in the dielectric constant of the gold surface.

Separation of $\lambda D N A$. We tested the separations of long DNA by NFCE at pH values ranging from 7.0 to 9.0; the numbers of resolved peaks decreased and the spikes increased with increasing $\mathrm{pH}$. The problems that occurred at higher $\mathrm{pH}$ are mainly due to greater amounts of sodium citrate added (current $>40 \mu \mathrm{A}$ and thus high Joule heats) and decreases in adsorption of $\mathrm{EtBr}$ on the GNPPs. Figure 1 indicates that the separation of $\lambda$-DNA fragments $(0.12-23.1 \mathrm{kbp})$ by NFCE was successful at $\mathrm{pH} 7.0$ using $10 \times$ (10 times the concentration of the original GNPs) GNPPs containing $\mathrm{EtBr}(2.0 \mu \mathrm{g} / \mathrm{mL})$. It is important to point out that the separation was unsuccessful when using the supernatant after the third centrifugation, polymer solutions $(0.0005-0.5 \%$, or $10 \times$ GNPs prepared in $10 \mathrm{mM} \mathrm{GC}$ buffer (pH 7.0) containing $\operatorname{EtBr}(2.0 \mu \mathrm{g} / \mathrm{mL})$. When we added a $0.0005 \%$ polymer solution to the 10x GNPPs solution, the separation efficiency was lost (not shown). Thus, it is extremely important to perform the washing and centrifuging cycles in triplicate to remove excess polymers from the GNPPs.

Interestingly, we have found that the resolution of adjacent DNA pairs depends on the ratio of the concentrations of EtBr and GNPPs. The suitable concentrations of EtBr for the separation of $\lambda$-DNA by NFCE using $5 \times$ and $10 \times$ GNPPs were 1.0 and 2.0 $\mu \mathrm{g} / \mathrm{mL}$, respectively. The $\mathrm{EtBr} / \mathrm{GNPP}$ dependence is also supported by the fact that the separation time is not inversely proportional to the GNPP concentration at a constant EtBr concentration $(2.0 \mu \mathrm{g} / \mathrm{mL}$ in Figure 1$)$. If the separation is related to the interaction between DNA and GNPPs, the separation time should increase with increasing GNPP concentration since the electrophoretic mobility of DNA decreases once it interacts with the neutral GNPPs. The loss of resolution when using $8 \times$ GNPPs containing $2.0 \mu \mathrm{g} / \mathrm{mL} \mathrm{EtBr}$ is because of partial aggregation of GNPPs and a greater excess amount of EtBr in the bulk solution that weakens the interaction between DNA and GNPPs.

(32) Neiman, B.; Grushka, E.; Lev, O. Anal. Chem. 2001, 73, 5220-5227.

(33) Pumera, M .; Wang, J.; Grushka, E.; Polsky, R. Anal. Chem. 2001, 73, 56255628.

(34) Lin, Y.-W.; Huang, M.-J .; Chang, H.-T. J. Chromatogr., A 2003, 1014, 4755.

(35) Huang, C.-C.; Huang, Y.-F.; Chang, H.-T. Nanosci., Nanotechnol., in press.

(36) Mayer, A. B. R. Polym. Adv. Technol. 2001, 12, 96-106.

(37) Lafuma, F.; Wong, K.; Cabane, B. J. Colloid Interface Sci. 1991, 143, 9-21.
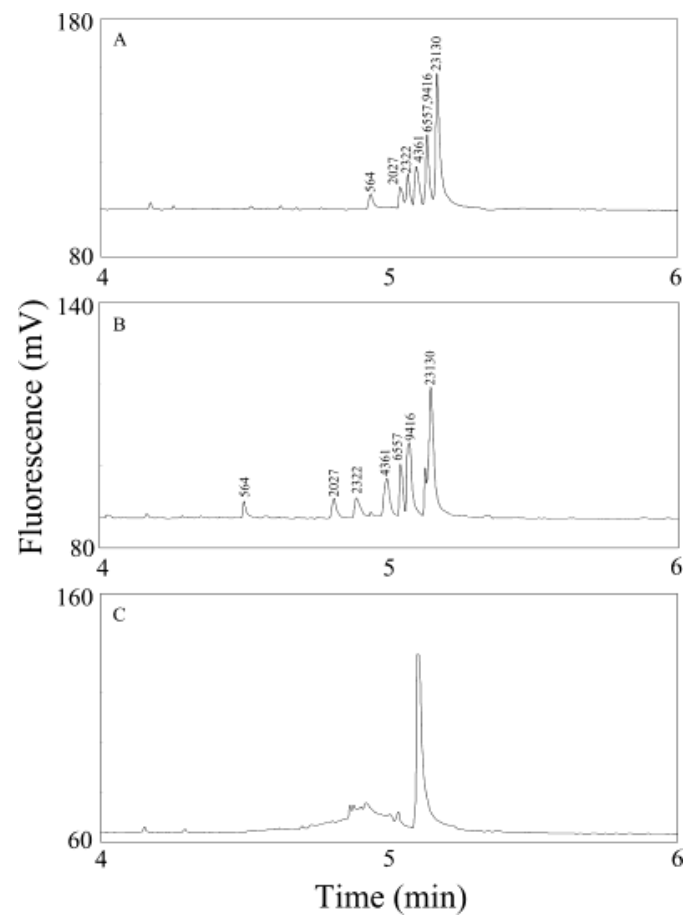

Figure 1. Separation of $\lambda$-DNA fragments $(10.0 \mu \mathrm{g} / \mathrm{mL})$ using $(A)$ $13 \times$ GNPPs, (B) $10 \times$ GNPPs, and (C) $8 \times$ GNPPs containing $\mathrm{EtBr}$ $(2.0 \mu \mathrm{g} / \mathrm{mL})$. The bp numbers of the corresponding DNA fragments are indicated. GNPPs were prepared in $10 \mathrm{mM} \mathrm{GC}$ buffer at $\mathrm{pH}$ 7.0. Fused-silica capillary: $365-\mu \mathrm{m}$ o.d., $75-\mu \mathrm{m}$ i.d., $40-\mathrm{cm}$ total length, and $30-\mathrm{cm}$ effective length. Electrophoresis conditions: pressure injection at $20 \mathrm{~cm}$ for $5 \mathrm{~s}$; separation at $-5 \mathrm{kV}$.

To test these hypotheses, we conducted the separations using $5 \times$ GNPPs containing $\mathrm{EtBr}$ at concentrations of less than $2.0 \mu \mathrm{g} / \mathrm{mL}$. The results depicted in Figure 2 suggest that the separation was successful and reproducible only in the case when $1.0 \mu \mathrm{g} / \mathrm{mL} \mathrm{EtBr}$ was used (RSD of the migration time for 23.1 $\mathrm{kbp}$ in triplicate runs is less than $1.0 \%$. The separation failed in the case when $2.0 \mu \mathrm{g} / \mathrm{mL} E t B r$ was used, which again shows the deleterious effect of the presence of excess $\mathrm{EtBr}$ in the bulk solution. Because the weak fluorescence $\left(\lambda_{\mathrm{ex}}=480 \mathrm{~nm}, \lambda_{\mathrm{em}}=\right.$ $610 \mathrm{~nm}$ ) of $\mathrm{EtBr}$ is quenched by the GNPPs through an energytransfer mechanism, an increase in the observed fluorescence (depicted in the inset in Figure 3) suggests the existence of free $\mathrm{EtB} r$ in the bulk solution. From the inflection point of the plots of fluorescence versus $\mathrm{EtBr}$ concentration (up to $5.0 \mu \mathrm{g} / \mathrm{mL}$ ), we estimated the saturation concentration of $\mathrm{EtBr}$ to be $1.2 \mu \mathrm{g} / \mathrm{mL}$. This concentration infers to that there are $\sim 2240 \mathrm{EtBr}$ molecules/ GNPP. To further clarify the deleterious effect of excess $E t B r$, we also collected UV-visible absorption spectra of the $5 \times$ GNPPs in the presence of different amounts of EtBr (Figure 3). In the absorption spectrum recorded using $2.0 \mu \mathrm{g} / \mathrm{mL} \mathrm{EtBr}$, particle aggregation is indicated by a broad, red-shifted shoulder for the SPR band. Thus, the loss of efficiency and reproducibility, and the presence of more spikes, in the nonoptimized NFCE runs are due mainly to aggregation of the GNPPs.

Salt Dependence. We have shown that the efficiency is greater when the DNA separation is conducted in the presence of small amounts of salt, mainly because DNA becomes more compact and possesses weaker interaction with the capillary wall. ${ }^{38}$ As expected, Figure 4A shows the separation time was shorter 


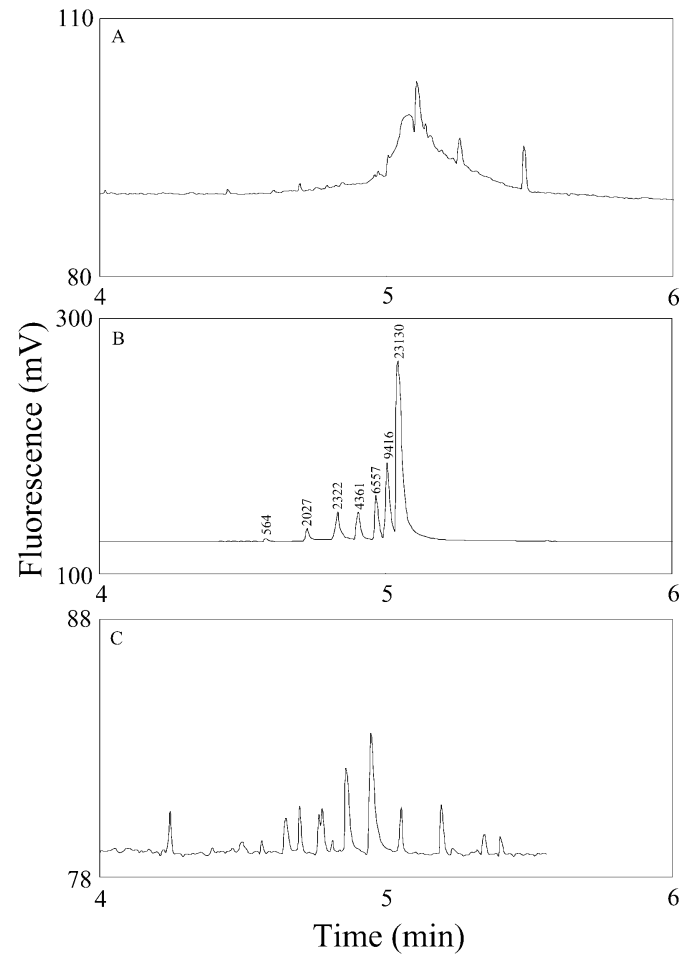

Figure 2. Separation of $\lambda$-DNA fragments $(10.0 \mu \mathrm{g} / \mathrm{mL})$ using $5 \times$ GNPPs containing (A) 2.0, (B) 1.0, and (C) $0.1 \mu \mathrm{g} / \mathrm{mL}$ EtBr. Other conditions are the same as those in Figure 1.

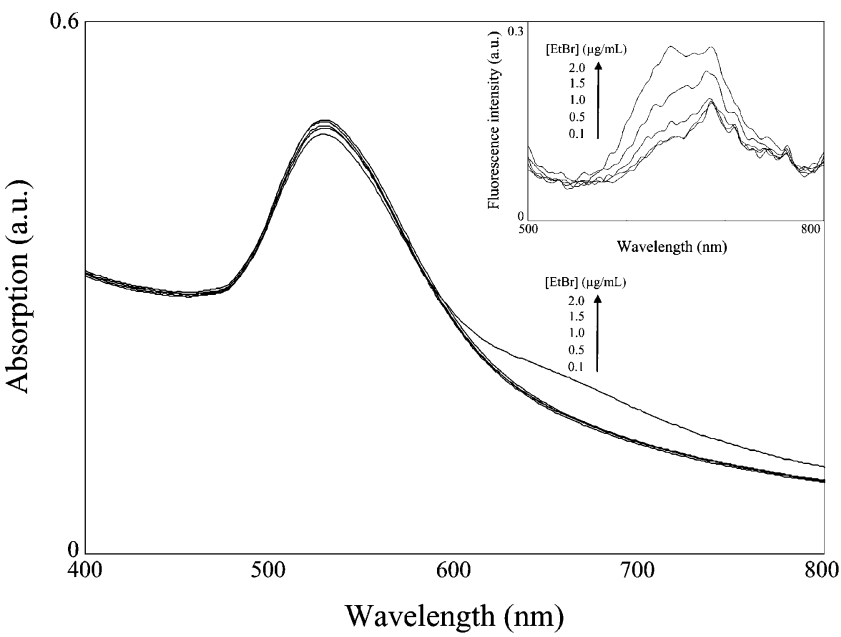

Figure 3. UV-visible absorption and emission spectra (inset) of $5 \times$ GNPPs containing 2.0, 1.5, 1.0, 0.5 , and $0.1 \mu \mathrm{g} / \mathrm{mL} \mathrm{EtBr}$, respectively. The SPR band's absorbance at $530 \mathrm{~nm}$ slightly decreases with increasing $\mathrm{EtBr}$ concentration when it is greater than $0.5 \mu \mathrm{g} / \mathrm{mL}$.

$(<5 \mathrm{~min})$, while the resolution increased in the presence of $0.1 \mathrm{mM} \mathrm{NaCl}$. We note that the plate numbers for the 4.3- and 23.1-kbp fragments are $1.3 \times 10^{6}$ and $6.0 \times 10^{5}$, respectively. Although the resolution of $\lambda$-DNA ( $>2027 \mathrm{bp}$ ) further increased when $1 \mathrm{mM} \mathrm{NaCl}$ was used (Figure $4 \mathrm{~B}$ ), it took longer mainly because of the decrease in the $\zeta$ potential of the DNA fragments at higher ionic strength. Although we did not see an apparent salt dependence on the SPR band of the GNPPs, salt might also affect the polymer conformation on the GNPPs. ${ }^{37,39,40}$ Figure 4C

(38) Hsieh, M.-M .; Chang, P.-L.; Chang, H.-T. Electrophoresis 2002, 23, 23882393.
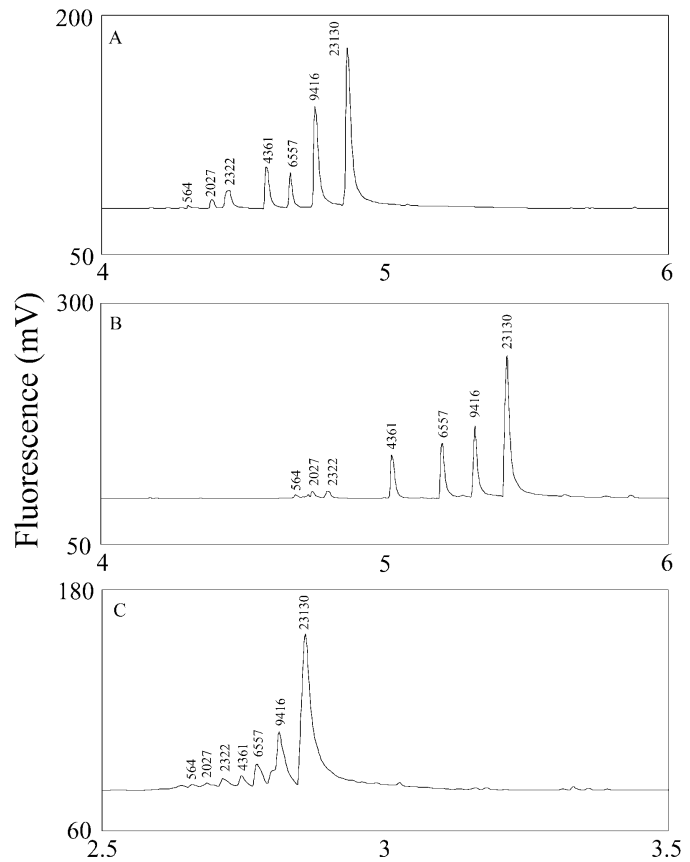

Time (min)

Figure 4. Separation of $\lambda$-DNA fragments $(10.0 \mu \mathrm{g} / \mathrm{mL})$ using $5 \times$ GNPPs containing $\operatorname{EtBr}(1.0 \mu \mathrm{g} / \mathrm{mL})$. The GNPP solutions contained $0.1 \mathrm{mM} \mathrm{NaCl}$ in $(A)$ and $(C)$ and $1.0 \mathrm{mM} \mathrm{NaCl}$ in $(B)$. The separations were conducted at $-5 \mathrm{kV}$ in $(\mathrm{A})$ and $(\mathrm{B})$ and $-10 \mathrm{kV}$ in $(\mathrm{C})$. Other conditions are the same as those in Figure 1.

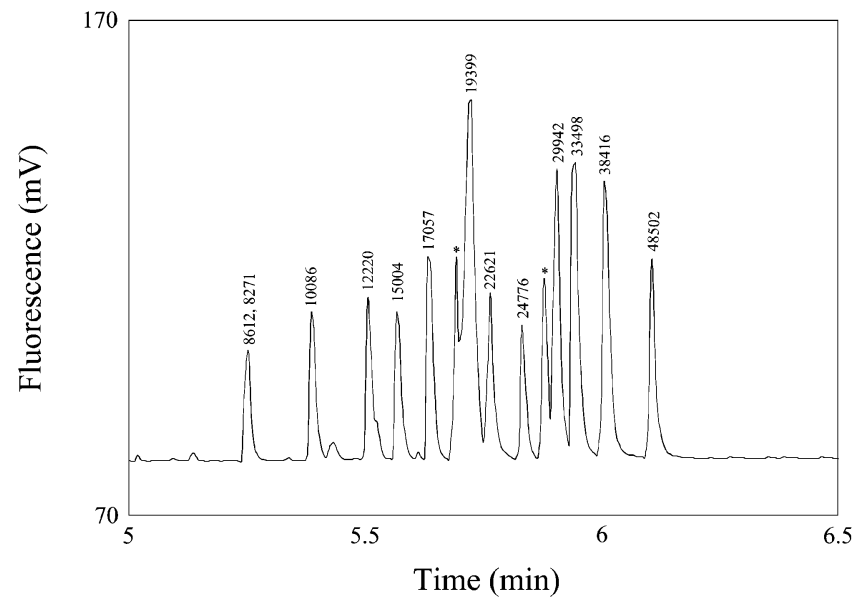

Figure 5. Separation of HMW DNA fragments $(10.0 \mu \mathrm{g} / \mathrm{mL})$ using $5 \times$ GNPPs containing $\operatorname{EtBr}(0.5 \mu \mathrm{g} / \mathrm{mL})$. Other conditions are as the same as those in Figure 1.

presents a high-speed separation ( $<3.0 \mathrm{~min}$ ) of $\lambda$-DNA by NFCE under an electric field of $-250 \mathrm{~V} / \mathrm{cm}(-10 \mathrm{kV})$.

Separation of HMW DNA. Figure 5 shows that DNA fragments with sizes ranging from 8.2 to $48.5 \mathrm{kbp}$ were well resolved within $7 \mathrm{~min}$, except for the 8.2 - and $8.6-\mathrm{kbp}$ fragments. The two reproducible peaks marked with asterisks (RSD values of the migration times in triplicate runs are less than $1.9 \%$ that elute just prior to the 19.4- and 29.9-kbp fragments are not observed in the electropherogram obtained from the supplier (by gel electrophoresis). We note that the plate numbers for the 10.1-,

(39) Gittins, D. I.; Garuso, F. J. Phys. Chem. 2001, 105, 6846-6852.

(40) Liu, S.; Weaver, J. V. M .; Save, M .; Armes, S. P. Langmuir 2002, 18, 8350 8357. 
Table 1. Comparison of Migration Time, Reproducibility, and Resolution Using GNPPs under Different Conditions

\begin{tabular}{|c|c|c|c|c|c|c|c|c|c|}
\hline & & migration & $\operatorname{me}(\min )^{e}$ & & & resolutior & bp/ bp) & & \\
\hline & & 564 bp & 23130 bp & $23130 / 9416$ & $9416 / 6557$ & $6557 / 4361$ & $4361 / 2322$ & $2322 / 2027$ & $2027 / 564$ \\
\hline [GNPPs] $^{\mathrm{a}}$ & $8 x$ & $d$ & $5.11(3.1 \%)$ & d & d & d & $d$ & $d$ & $\mathrm{~d}$ \\
\hline & $10 x$ & $4.50(1.2 \%)$ & $5.15(0.9 \%)$ & 1.6 & 1.0 & 1.5 & 2.9 & 2.0 & 10.1 \\
\hline & $13 x$ & $4.94(2.3 \%)$ & $5.17(1.8 \%)$ & 1.1 & 0.0 & 1.5 & 1.0 & 1.0 & 3.7 \\
\hline$[\mathrm{EtBr}](\mu \mathrm{g} / \mathrm{mL})^{\mathrm{b}}$ & 1.0 & 4.59 (1.1\%) & $5.05(1.0 \%)$ & 1.1 & 1.3 & 2.2 & 2.6 & 3.8 & 5.2 \\
\hline & 2.0 & $d$ & $5.11(2.9 \%)$ & d & $d$ & d & d & $d$ & $\mathrm{~d}$ \\
\hline$[\mathrm{NaCl}](\mathrm{mM})^{\mathrm{c}}$ & 0.1 & $4.36(1.5 \%)$ & $4.87(1.3 \%)$ & 3.1 & 2.9 & 2.8 & 3.7 & 1.8 & 3.1 \\
\hline & 1.0 & $4.69(1.3 \%)$ & $5.43(1.1 \%)$ & 3.4 & 3.8 & 6.0 & 6.7 & 1.9 & 2.0 \\
\hline
\end{tabular}

a Conditions are the same as those in Figure $1 .{ }^{b}$ Conditions are the same as those in Figure $2 .{ }^{c}$ Conditions are the same as those in Figure 4. ${ }^{d} \mathrm{~A}$ broad and unresolved peak for the fragments besides $23.1 \mathrm{kbp}$. ${ }^{\mathrm{e}} \mathrm{M}$ ean $(\mathrm{n}=3)$ (RSD).

24.8-, and 48.5-kbp fragments are $1.8 \times 10^{6}, 2.2 \times 10^{6}$, and $2.1 \times$ $10^{6}$, respectively. To the best of our knowledge, this is the first CE method that provides such high speeds and efficiencies for the separation of long strands of DNA.

Separation Mechanism. As in the transient entanglement mechanism, ${ }^{17}$ a DNA molecule temporarily intertwines with the polymers adsorbed on a GNP with which it collides during electrophoretic separation. The nearly neutral GNPPs resist the flow and slow the migration of the DNA. Compared with the free linear polymers, the polymers adsorbed on the GNPs are stiffer and less extended, depending on the size of the GNPs and the length of the polymer chain, and, thus, become slightly deformed under the flow. ${ }^{26,41-43}$ This assumption is supported by the observation that DNA separations by NFCE using GNPs modified with shorter versions of the same neutral polymers, which are not presented toward the bulk solution to such an extent, are not successful under the same conditions. Because of the strong intercalation between DNA and EtBr adsorbed on the GNPPS, the mutual disengagement time of the intertwined GNPPs and DNA should be relatively long. Our reasoning is supported by the fact that the resolving power of separation decreases with increasing amounts of free EtBr in the bulk solution (Table 1 ). M ore importantly, the GNPP $\left(2.0 \times 10^{8} \mathrm{~g} / \mathrm{mol}\right.$ for the 32-nm GNP) is much heavier than the linear polymer, and thus, it provides a greater capability to slow the entangled DNA fragments. In this manner, the role that the GNPPs play is similar to that of streptavidin (i.e., providing extra friction) in end-labeled free solution CE.44,45 Since long DNA fragments (e.g., the gyration radius and full stretched length for $48.5 \mathrm{kbp}$ are $520 \mathrm{~nm}$ and 21 $\mu \mathrm{m}$, respectively) ${ }^{46}$ have a greater probability to interact with more

(41) Nowicki, W. M acromolecules 2002, 35, 1424-1436.

(42) Chaplain, V.; Janex, M. L.; Lafuma, F.; Graillat, C.; Audebert, R. Colloid Polym. Sci. 1995, 273, 984-993.

(43) Aubouy, M .; Raphaël, E. M acromolecules 1998, 31, 4357-4363.

(44) Mayer, P.; Slater, G. W.; Drouin, G. Anal. Chem. 1994, 66, 1777-1780.

(45) Vreeland, W. N.; M eagher, R. J.; Barron, A. E. Anal. Chem. 2002, 74, 43284333.

(46) Bakajin, O. B.; Duke, T. A.; Chou, C. F.; Chan, S. S.; Austin, R. H.; Cox, E. C. Phys. Rev. Lett. 1998, 80, 2737-2740. than one GNPP, depending on the DNA size and conformation, the dragging forces are stronger for long DNA fragments compared to short ones. As a result, the mobility of long DNA is smaller than a short one. Based on the proposed mechanism, band broadening and thus the loss of resolution for DNA take place as a result of the polydispersity of the GNPPs. In other words, the resolving power shown in Table 1 can be further improved if monodispersed GNPPs are made.

\section{CONCLUSION}

We have demonstrated the use of GNPPs for the separation of long double strands of DNA by CE, with the advantages of high efficiency, high speed, simplicity, and reproducibility. This study reveals that the resolving power of separation depends on interactions between DNA and PEO adsorbed on GN Ps (GNPPs), which slow the migration of the DNA molecules. On the basis that 13- and 56-nm GNPPs (coated with the same polymer) do not provide such high resolving power as do 32-nm GNPPs, we anticipate that separations performed by NFCE should be further optimized by using differently sized and shaped GNPPs (different natures of the nanoparticles and the polymer, e.g., size, structure, and hydrophilicity). Since the polymers are attached to the GNPS and are not dragged into an outlet vial by DNA, NFCE should provide the advantage of ease of DNA cleanup for further identification and use. Taken together with our previous results, ${ }^{26}$ we have realized the great potential of polymer-adsorbed nanoparticles for new applications in separation science and the life sciences.

\section{ACKNOWLEDGMENT}

This work was supported by the National Science Council of the Republic of China under Contracts NSC 92-2113-M -002-048 and NSC 92-2120-M -002-001.

Received for review August 4, 2003. Accepted October 20, 2003.

AC034908U 